Agro-Science Journal of Tropical Agriculture, Food, Environment and Extension Volume 18 Number 1 (January 2019) pp. 30-38

ISSN 1119-7455

\title{
INFLUENCE OF PLANT POPULATION ON FRUIT AND SEED YIELD CHARACTERS OF CAYENNE PEPPER (Capsicum frutescens L.) GENOTYPES
}

\author{
${ }^{* 1}$ Abdul-Rafiu A.M., ${ }^{2}$ Adebisi M.A., ${ }^{2}$ Daniel I.O., ${ }^{3}$ Bodunde J.G., \\ ${ }^{2}$ Ajayi O.O., ${ }^{1}$ Muhammad S.M. and ${ }^{4}$ Dixon H.G. \\ ${ }^{1}$ Seed Technology Unit, ${ }^{4}$ Farming Systems Research Program, \\ National Horticultural Research Institute (NIHORT), PMB 5432, Ibadan, Oyo State, Nigeria \\ ${ }^{2}$ Department of Plant Breeding and Seed Technology, ${ }^{3}$ Department of Horticulture, \\ Federal University of Agriculture, Abeokuta, PMB 2240, Abeokuta, Ogun State, Nigeria \\ Corresponding author’s email: monsurayoola@yahoo.co.uk
}

\begin{abstract}
This study assessed the influence of three plant populations (18518, 27777 and 40000 plants ha $\left.{ }^{-1}\right)$ on fruit and seed yield characters in 16 genotypes of Capsicum frutescens in 2010 and 2011 cropping years using a $3 x 16$ split plot arrangement fitted into a randomized complete block design. Plant population and genotype formed main and sub-plots, respectively. Data collected on fruit and seed yield characters were subjected to analysis of variance after which means were separated using Fisher's Least Significant Difference. Correlation analysis was also carried out among the characters. Significant and highest $(P<0.01)$ number of fruits per plant, single fruit weight, fruit weight per plant, number of seeds per fruit, 100 seed weight, seed weight per plant and seed weight per fruit were obtained under 18518 plants ha $a^{-1}$ while highest $(P<0.05)$ fruit yield $\mathrm{ha}^{-1}$ (11.3 tons) and seed yield $\mathrm{ha}^{-1}(698.7 \mathrm{~kg})$ were obtained under 40000 plants ha ${ }^{-1}$. Top fruit and seed yielding genotypes across the three plant population were PP9955-15 and Chilli 14, respectively. Number of fruits per plant showed negative and highly significant correlation with single fruit weight, fruit length, fruit width, number of seeds per fruit, 100-seed weight and seed weight per fruit. Significant positive or negative correlations were also observed among other characters. Plant population of 40,000 ha ${ }^{-1}$ using $50 \times 50 \mathrm{~cm}$ spacing is recommended for high fruit and seed yield in C. frutescens production.
\end{abstract}

Key words: Cayenne pepper, plant population, seed production efficiency, seed yield

\section{INTRODUCTION}

A uniform distribution of plants per unit area is a prerequisite for yield stability (Diepenbrock, 2000). Studies on plant density for different types of pepper (Capsicum sp.) including bell, cayenne, pepperoncini and jalapeno have shown that plant density and plant arrangement can influence plant development, growth and the marketable yield of peppers (Khasmakhi-Sabet et al., 2009). Plant density is an important determinant of yield (per unit area) in most crops. Yield per unit area tends to increase as plant density increases up to a point and then declines (Akintoye et al., 2009). Norman (1992) recommended a spacing of $60 \mathrm{~cm} \times 60 \mathrm{~cm}$ for bell pepper and $90 \mathrm{~cm}$ x $60 \mathrm{~cm}$ or $90 \times 90 \mathrm{~cm}$ for hot pepper amounting to 27777, 18518 and 12345 plants $\mathrm{ha}^{-1}$, respectively. Ado and Asiribo (1989) were reported by Adetula and Olakojo (2006) to have recommended $75 \mathrm{~cm} \mathrm{x} 40 \mathrm{~cm}$ giving a population density of 33333 plants ha ${ }^{-1}$ for $C$. frutescens production. Berke et al. (2005) reported $1.5 \mathrm{~m}$ wide beds (furrow to furrow), $30 \mathrm{~cm}$ high, two rows per bed at $55 \mathrm{~cm}$ apart, with $45 \mathrm{~cm}$ between plants within rows, for a plant population density of 29,630 plants ha ${ }^{-1}$. FAO (2004) observed that the spacing between the rows and within the rows in peppers will depend on the vigour and growth habit of individual varieties being grown. The wider spacing is commonly used where leaf, stem and fruit diseases are likely to occur (FAO, 2004). Unless planting on ridges or mounds, the young pepper seedlings are planted in rows five feet apart and three feet within the rows which translates to $150 \mathrm{~cm} \mathrm{x} 90 \mathrm{~cm}$ (FAO, 2004). This spacing will provide a final plant stand of about 7,410 plants $\mathrm{ha}^{-1}$ while a spacing of four feet between the rows and three feet within the rows $(120 \mathrm{~cm} \times 91 \mathrm{~cm})$ will give 8966 plants $\mathrm{ha}^{-1}$. Plant spacing of 40 to $60 \times 90 \mathrm{~cm}$ resulting in 27778 to 18519 plants $\mathrm{ha}^{-1}$ was recommended by FAO (2004) and Herman et al. (2011). Plant spacing of $60 \times 60 \mathrm{~cm}$ has also been suggested by Herman et al. (2011) for hot pepper (Capsicum chinense Jacq.) production in Trinidad and Tobago. This implies that there is an opportunity to choose from wide range of spacing to use considering the 
species to grow. Purpose of production may also influence plant spacing as closer spacings are favoured for production of fruits for canning. For example, George (2009) suggested 30-60 cm within rows and $45-90 \mathrm{~cm}$ between rows giving a range of 18,519 and 74,074 plants ha ${ }^{-1}$ respectively. In cover crops, highest leaf yield has been reported by Obalum et al. (2017) in fluted pumpkin planted at closer spacing of $25 \mathrm{~cm} \times 25 \mathrm{~cm}$. Also, Adubasim et al. (2017) obtained highest tuber yield in sweet potato planted at close spacing of $30 \mathrm{~cm} \mathrm{x}$ $60 \mathrm{~cm}$. Essentially, plant density plays a crucial role and contributes to the yield and marketable yield properties which in turn translate to economic returns. Literatures have shown that different planting spacing are being used while it has also been revealed that canopy size and plant morphology of the pepper species are different. There are also very few reports on seed yield and quality with regards to plant population in pepper. Similarly, information relating to planting population densities for seed production in unbedded (flat) field is relatively scarce. Therefore, there is need to determine which among these population densities will be most suitable and adoptable for higher yield in cayenne pepper especially for seed production under humid tropical conditions. Hence, this study was conducted to evaluate the effect of plant population densities on fruit and seed yield components in genotypes of cayenne pepper (C. frutescens).

\section{MATERIALS AND METHODS}

Seeds of 16 cayenne pepper genotypes were used for the study. The nursery was conducted at the screen house of the College of Plant Science and Crop Production, Federal University of Agriculture, Abeokuta (FUNAAB) while the field trial was conducted at the Teaching and Research Farm (FUNAAB) under rain-fed field conditions in 2010 and 2011 cropping years. Average rainfall during the period of the study was $600 \mathrm{~mm}$ and 335 $\mathrm{mm}$ for the two years respectively (rainfall data from the Dept of Agrometerology and Water Resources, FUNAAB). The study site is located between Latitude $7^{\circ} \mathrm{N} 37^{\prime} \mathrm{N}$, longitude $3^{\circ} 89^{\prime} \mathrm{E}$ and altitude of $210 \mathrm{~m}$ while the soil is loamy sand.

Seeds of 16 genotypes of cayenne pepper were sown in the trays filled with sterilized topsoil. Two sowings were carried out to raise seedlings for the field evaluation which was carried out in two years. The first was between Jul. 18 and Aug. 26, 2010 and the second was between Jul. 29th and Sep. 5th, 2011. The seedlings were monitored daily in the nursery and watering was carried out as required. Land preparation was carried out (mechanically) by ploughing twice with a space of two weeks between the first and second. Harrowing was carried out three days after the second ploughing. The field was laid out in a $3 \times 16$ split - plot fitted into randomized complete block design with three replications. Plant populations formed main plot while the genotype formed the sub-plot. The seedlings were transplanted at five weeks after sowing in both years under three plant populations; 40000 (using 50 x $50 \mathrm{~cm}$ spacing), 27777 (using 60 x $60 \mathrm{~cm}$ ) and 18518 (using 90 x $60 \mathrm{~cm}$ ) plants $\mathrm{ha}^{-1}$. Each genotype, comprising three rows and a total of 24 plants per plot in each replicate. Weeding was done manually with hoes as urea and NPK fertilizers were applied in split doses to meet the nutrient requirement of $130 \mathrm{~kg} / \mathrm{ha} \mathrm{N}, 80 \mathrm{~kg} / \mathrm{ha} \mathrm{P}$ and $110 \mathrm{~kg} / \mathrm{ha} \mathrm{K}$ (Grubben and Tahir, 2004).

\section{Data collection}

Six plants in the middle row were selected for harvesting in each plot and data were collected on fruit and seed yield parameters which include:

i. Number of fruits per plant - This was determined as total number of fruits harvested in each plot over the life span of the crop divided by number of plants.

ii. Single fruit weight - This was determined by weighing 20 fruits from each plot and dividing the value by 20 .

iii. Fruit length - Length of 20 fruits sampled randomly from the second harvest were measured with a metre rule and then computed to average.

iv. Fruit weight per plant - This was determined by weighing total number of fruits harvested per plot divided by number of plants per plot.

v. Fruit width - Width of 20 fruits sampled randomly from the second harvest were measured using a vernier calliper and then computed to average.

vi. Number of seeds per fruit - This was determined as average number of seeds of 20 fruits sampled randomly from the second harvest in each plot.

vii. Seed weight per fruit - Seeds obtained from (vi) above was weighed and recorded.

viii. 100 seed weight - 100 seeds in three replications were counted from (vi) above and weighed in gram.

ix. Seed weight per plant - this was determined by multiplying number of seeds per fruit (obtained previously above) by number of fruit per plant.

x. Fruit yield per hectare - This was estimated by multiplying fruit weight per plant by number of plants per hectare.

xi. Seed yield per hectare - This was estimated by multiplying seed weight per plant by number of plants per hectare. Seed production efficiency (SPE): This was determined according to Ogunbodede and Ogunremi (1986). $\mathrm{SPE}=\underline{\text { Seed weight }} \times 100$ Fruit weight 


\begin{abstract}
Data Analysis
Data collected were subjected to analysis of variance while significant means were separated using Fisher's Least Significant Difference at 5\% level of probability. Pearson correlation co-efficient among fruit and seed yield characters were computed.
\end{abstract}

\section{RESULTS}

The effect of plant population density on the fruit and seed yield parameters evaluated across genotypes of cayenne pepper ( $C$. frutescens) showed that number of fruits per plant, single fruit weight, fruit weight per plant, fruit length, number of seed per fruit, 100 seed weight, seed weight per plant and seed weight per fruit were significantly highest under 18518 plants ha ${ }^{-1}(60 \times 90 \mathrm{~cm})$ while similar values were recorded under 27777 plants $\mathrm{ha}^{-1}(60 \times 60 \mathrm{~cm})$ and 40000 plants $\mathrm{ha}^{-1}(50 \times 50$ $\mathrm{cm})$. In contrast, pepper plants grown under 40000 plants ha ${ }^{-1}$ had the longest fruit $(8.64 \mathrm{~cm})$ as well as highest fruit and seed yield per hectare (11.32 tons and $698.70 \mathrm{~kg}$, respectively). The shortest fruits were observed on plants grown under 27777 plants ha $^{-1}$ with $7.67 \mathrm{~cm}$ (Table 1). Mean performance of fruit and seed yield characters of the 16 cayenne pepper genotypes across plant population density (Table 2) revealed that Ata wewe was significantly highest in terms of number of fruits (207.83), followed by Cayenne slim (125.72) and Chilli 14 (100.39) while PP9955-15 (51.61) had the lowest number of fruits. Also, PP9955-15 had significantly largest single fruit weight $(10.79 \mathrm{~g})$ followed by PP0337-7562 (7.94 g) while the smallest was recorded in Ata wewe $(1.07 \mathrm{~g})$. Fruit weight per plant was largest in PP9955-15 with $565.8 \mathrm{~g}$, followed by PP0437-7509 (480.6 g), ICPN19-07 (457.3 g) and PP0337-7562 (454.0 g).The lowest fruit weight per plant was observed in Sakarho, IA108-3 and Cayenne slim with 153.7, 154.9 and $185.9 \mathrm{~g}$, respectively. For fruit length, ICPN $19-07$ and PP0437-7509 recorded significantly highest values with $12.80 \mathrm{~cm}$ and $12.38 \mathrm{~cm}$, respectively while the lowest values were observed in Ata wewe $(3.99 \mathrm{~cm})$ and $B G 4$ $(4.32 \mathrm{~cm})$. Fruits of $P P 9955-15$ and $B G 3$ recorded significant $(\mathrm{P}>0.05)$ widest width of 2.38 and 2.23 $\mathrm{cm}$, respectively whereas Ata wewe, Cayenne slim and Bird eye 11 recorded significant lowest fruit width among the genotypes. Furthermore, significant highest fruit yield per hectare was recorded in PP9955-15 with 16.36 tons while the lowest was observed in IA108-3 with 4.19 tons. Among the genotypes, highest number of seed per fruits was observed in ICPN $19-07$ with 89.78 while the lowest number of seed per fruit was observed in Ata wewe with 41.22. Genotype PP0337-7562 had the highest 100-seed weight $(0.458 \mathrm{~g})$ followed by $B G 4(0.448 \mathrm{~g})$ whereas the lowest 100-seed weight was recorded in Ata wewe with $0.321 \mathrm{~g}$. Furthermore, seed weight per plant was highest in Chilli 14 with $31.26 \mathrm{~g}$ while NHVIA recorded the lowest value $(11.48 \mathrm{~g})$. On seed production efficiency (SPE), the highest was observed in Cayenne slim and Ata wewe with values of $13.9 \%$ and $12.8 \%$, respectively. Sakarho, Chilli 14 and Bird eye 11 were intermediate in SPE but NHV1A and PP9955-15 had the lowest performance $(3.5 \%$ and $3.0 \%$ respectively). The highest seed weight per fruit were obtained in ICPN 19 - 07 (0.393 g) followed by Chilli 14 $(0.311 \mathrm{~g})$ and PP9955 - 15 (0.306 g) whereas Ata wewe $(0.132 \mathrm{~g})$, Bird eye 11 (0.179 g), Ikire (0.183 g) and Cayenne slim (0.196 g) had lowest values. Seed yield per ha among the genotypes showed similar trend as Chilli 14 gave the highest seed yield of $888.00 \mathrm{~kg} \mathrm{ha}^{-1}$ followed by Ata wewe with $761.40 \mathrm{~kg} \mathrm{ha}^{-1}$. The lowest seed yield of $316.90 \mathrm{~kg}$ $\mathrm{ha}^{-1}$ was obtained in NHVIA. The fruit yield per hectare for the cayenne pepper genotypes under three plant population densities (Table 3 ) indicated that at 18,518 plant population, $P P 9955-15$ and PP0437-7509 were observed with the highest fruit yield of 9.69 and $8.39 \mathrm{t} \mathrm{ha}^{-1}$, respectively. Four genotypes (PP0337-7562, ICPN 19-07, Chilli 14, and $N H V 1 B)$ also produced higher fruit yield ranging between 6.16-7.85 $\mathrm{t} \mathrm{ha}^{-1}$. Lowest fruit yield under 18,518 plants population was observed in cayenne slim, Ata wewe, IA108-3, Sakarho and Bird eye 11 with values ranging between 2.14 and $3.77 \mathrm{t} \mathrm{ha}^{-1}$. Also, the fruits under 27777 plants $\mathrm{ha}^{-1}$ were significantly highest in ICPN 19-07 and $P P 9955-15$. It was also observed that fruit yield was significantly higher and similar under plant population of 27777 and 40000 per hectare among the genotypes. In the comparison of each genotype under the three densities, significant variation was observed for fruit yield under the three plant population for all the genotypes. Higher fruit yield were recorded under 27777 and 40000 plant densities except in all the genotypes PP9955-15 where 40000 plants gave the highest fruit yield (22.19 tons). Furthermore, seed yield $\mathrm{ha}^{-1}$ also varied significantly among the genotypes under the three plant populations. At 18,518 plants $\mathrm{ha}^{-1}$, Ata wewe, Chilli 14, and ICPN 19-07 gave highest seed yield of between 622.09 and $630.45 \mathrm{~kg} \mathrm{ha}^{-1}$ while IA108-3 produced the lowest (279.18 $\left.\mathrm{kg} \mathrm{ha}^{-1}\right)$. Seed yield increased significantly in Chilli 14 to 809.34 $\mathrm{kg} \mathrm{ha}^{-1}$ at 27,777 plants which was the highest while $298.74 \mathrm{~kg}$ per ha was recorded in NHV1A which was the lowest. At 40,000 plants population, seed yield further increased in Chilli 14 to 1224.10 $\mathrm{kg} \mathrm{ha}^{-1}$ which was the highest. The lowest seed yield under this plant population was recorded in NHVIA with $396.72 \mathrm{~kg} \mathrm{ha}^{-1}$. By comparing seed yield of each genotype under the three plant populations, all the genotypes recorded highest seed yield under 40000 plants ha ${ }^{-1}$. 
Table 1: Effect of plant population density on fruit and seed yield parameters evaluated across genotypes of cayenne pepper (C. frutescens)

Fruit and Seed yield characters

Number of fruits/plant

Single fruit weight $(\mathrm{g})$

Fruit weight /plant $(\mathrm{g})$

Fruit length $(\mathrm{cm})$

Plant population $\left(\mathrm{ha}^{-1}\right)$

18518 plants

87.34
5.28

390.90

8.83

5.52

Fruit yield per ha (tons)

Number of seeds per fruit

100 seed weight $(\mathrm{g})$

Seed yield/plant $(\mathrm{g})$

Seed weight/fruit (g)

66.69

0.407

22.40

0.271

414.90

27777 Plants
76.53
4.46
297.90
7.67
10.86
61.45
0.402
17.76
0.248
493.30

40000 plants

76.85
4.20

$4.20 \quad 0.36$

$283.10 \quad 24.33$

$8.64-0.18$

$\begin{array}{ll}8.642 & 0.75\end{array}$

$\begin{array}{ll}8.64 & 0.75 \\ 59.85 & 2.44\end{array}$

$\begin{array}{ll}59.85 & 2.44 \\ 0.401 & 0.002\end{array}$

$17.47-0.83$

$0.241-0.013$

22.64

Table 2: Mean performance of fruit and seed yield characters evaluated in 16 cayenne pepper genotypes across plant population density and cropping year

\begin{tabular}{|c|c|c|c|c|c|c|c|c|c|c|c|c|}
\hline Genotype & $\begin{array}{l}\text { Number of } \\
\text { fruits plt }^{-1}\end{array}$ & $\begin{array}{l}\text { Single fruit } \\
\text { weight }(\mathrm{g})\end{array}$ & $\begin{array}{l}\text { Fruit weight } \\
\mathrm{plt}^{-1}(\mathrm{~g})\end{array}$ & $\begin{array}{l}\text { Fruit length } \\
(\mathrm{cm})\end{array}$ & $\begin{array}{l}\text { Fruit width } \\
(\mathrm{cm})\end{array}$ & $\begin{array}{l}\text { Fruit yield } \\
\left(\mathrm{t} \mathrm{ha}^{-1}\right)\end{array}$ & $\begin{array}{l}\text { No of } \\
\text { seed fruit }{ }^{-1}\end{array}$ & $\begin{array}{l}100 \text { seed } \\
\text { weight }(\mathrm{g})\end{array}$ & $\begin{array}{l}\text { Seed weight } \\
\text { plt }^{-1}(\mathrm{~g})\end{array}$ & $\begin{array}{l}\text { SPE } \\
(\%)\end{array}$ & $\begin{array}{l}\text { Seed wt } \\
\text { fruit }^{-1}(\mathrm{~g})\end{array}$ & $\begin{array}{l}\text { Seed yield } \\
\left(\mathrm{kg} \mathrm{ha}^{-1}\right)\end{array}$ \\
\hline Cayenne slim & 125.72 & 1.50 & 185.9 & 7.15 & 0.97 & 5.30 & 48.61 & 0.402 & 24.86 & 13.9 & 0.196 & 685.20 \\
\hline Ata wewe & 207.83 & 1.07 & 224.4 & 3.99 & 0.86 & 6.39 & 41.22 & 0.321 & 27.56 & 12.8 & 0.132 & 761.40 \\
\hline IA108-3 & 52.61 & 2.94 & 154.9 & 6.97 & 1.70 & 4.19 & 62.61 & 0.383 & 12.71 & 8.9 & 0.230 & 350.43 \\
\hline Ikire & 74.89 & 4.11 & 312.9 & 10.21 & 1.31 & 8.93 & 45.33 & 0.406 & 13.77 & 4.6 & 0.183 & 382.00 \\
\hline Sakarho & 54.50 & 2.84 & 153.7 & 5.62 & 1.17 & 4.40 & 56.61 & 0.428 & 13.26 & 9.3 & 0.242 & 360.20 \\
\hline Chilli 14 & 100.39 & 3.99 & 402.3 & 5.43 & 1.82 & 11.48 & 85.17 & 0.365 & 31.26 & 8.0 & 0.311 & 888.00 \\
\hline NHV 1B & 72.89 & 4.93 & 373.6 & 8.50 & 1.88 & 10.57 & 75.72 & 0.383 & 21.80 & 6.1 & 0.291 & 599.80 \\
\hline NHV 1A & 56.61 & 5.74 & 325.0 & 8.82 & 1.77 & 9.29 & 53.39 & 0.378 & 11.48 & 3.5 & 0.202 & 316.90 \\
\hline PP9955 - 15 & 51.61 & 10.79 & 565.8 & 11.62 & 2.38 & 16.36 & 76.94 & 0.396 & 16.42 & 3.0 & 0.306 & 487.73 \\
\hline PP0337 - 7562 & 56.61 & 7.94 & 454.3 & 11.15 & 1.52 & 13.10 & 61.28 & 0.458 & 15.83 & 3.7 & 0.280 & 454.70 \\
\hline ICPN $19-07$ & 65.22 & 6.79 & 457.3 & 12.80 & 1.94 & 12.93 & 89.78 & 0.438 & 26.22 & 6.0 & 0.393 & 709.32 \\
\hline PP0437 - 7509 & 77.94 & 6.04 & 480.6 & 12.28 & 1.56 & 13.64 & 67.17 & 0.439 & 23.07 & 5.2 & 0.295 & 645.50 \\
\hline Bird eye 11 & 93.11 & 2.29 & 219.3 & 4.86 & 0.98 & 6.29 & 44.44 & 0.401 & 16.75 & 8.0 & 0.179 & 460.70 \\
\hline PP0438 - 8543 & 62.06 & 5.61 & 359.9 & 9.87 & 1.54 & 10.23 & 59.39 & 0.431 & 15.95 & 5.0 & 0.256 & 444.72 \\
\hline BG 4 & 69.33 & 3.90 & 271.1 & 4.32 & 1.56 & 7.71 & 61.00 & 0.448 & 18.93 & 7.3 & 0.273 & 531.82 \\
\hline BG 3 & 62.56 & 3.86 & 242.2 & 8.11 & 2.23 & 6.92 & 73.94 & 0.377 & 17.48 & 7.4 & 0.279 & 492.32 \\
\hline $\operatorname{LSD}(0.05)$ & 6.17 & 0.61 & 51.63 & 0.65 & 0.45 & 1.48 & 5.65 & 0.005 & 2.27 & 1.4 & 0.026 & 64.32 \\
\hline
\end{tabular}

$\begin{array}{lrrr}\mathrm{LSD}(0.05) & 6.17 & 0.61 & 51.63\end{array}$ 
The 100-seed weight of cayenne pepper genotypes under three plant densities (Table 5) shows that at 18518 plant ha $^{-1}$, PP0337-7562 had highest 100seed weight with $0.460 \mathrm{~g}$ closely followed by $B G 4$ (0.452 g), ICPN 19-07 (0.447 g) and PP0437-7509 $(0.446 \mathrm{~g})$ whereas Ata wewe recorded the lowest value of $0.324 \mathrm{~g}$ per 100 seed. The performance of the genotypes under 27,777 plant population density was similar to that under 18,518 plant density. The weight of 100 seed under 40000 plant population was significantly highest in PPO337$7562(0.453 \mathrm{~g})$ and this was closely followed by BG 4 (0.445 g), ICPN 19-01 (0.433 g) and PP04377509 (0.435 g) while Ata wewe still recorded the lowest value of $0.318 \mathrm{~g}$. By comparing each genotype under the three plant population densities, significant variation was observed for eight genotypes.

The Pearson correlation coefficients (from the pooled data of two years) among fruit and seed yield characters in cayenne pepper genotypes (Table 6) showed that most of the characters had significant positive or negative correlation among themselves. The result indicated that number of fruits per plant showed negative and highly significant correlation with single fruit weight, fruit length, fruit width, number of seeds per fruit, 100seed weight and seed weight per fruit with coefficient values of between $r-0.275$ and $r$ 0.449 . In contrast, positive and highly significant correlation values were recorded between number of fruits per plant and seed weight per plant, seed production efficiency (SPE) and seed yield per hectare with coefficient values of between $r-0.454$ and 0.616 across the three plant population densities. Positive and highly significant correlation existed between single fruit weight and fruit weight per plant, fruit length, fruit width, fruit yield per hectare, number of seeds per fruit, 100-seed weight and seed weight per fruit while significant and negative correlation was observed between single fruit weight and SPE. It was also observed that fruit length and fruit width exhibited positive and significant relationship with fruit yield per hectare, number of seeds per fruit, 100-seed weight and seed weight per fruit but significant and negative correlation with SPE. Fruit yield per ha also correlated positively with other characters except SPE.

\section{DISCUSSION}

Maximum seed yield and quality are among the major objectives of successful seed production programme. In this study, cayenne pepper fruit and seed yield characters were significantly $(P>0.05)$ affected by plant population density and genotype. Therefore, consideration should be given to plant population density and genotype in seed production of cayenne pepper. Alam et al. (2011) have earlier reported that successful cultivation of any crop depends on several factors but sowing time and plant population are more important for the production system of different crops. Also, Adebisi et al. (2005) identified plant population as a cardinal role in determining seed yield. The significant effect of plant population on seed yield characters of the cayenne pepper showed that as plant population density increased from 18518 to 40000 plants per hectare, fruit yield per hectare increased from 5.52 to 11.32 tons $\mathrm{ha}^{-1}$ (105.1\% increment) while seed yield per hectare increased significantly from 414 to $698.7 \mathrm{~kg} \mathrm{ha}^{-1}(68.8 \%$ increment). This shows that higher plant population density actually compensated for lower yield per plant and resulted in increased fruit and seed yield per area whereas bigger fruits did not compensate for fewer plants under low plant population as observed in the study.

On the other hand, all other fruit and seed yield characters such as fruit weight per plant, single fruit weight, number of seed per fruit, 100 seed weight, seed weight per plant and seed weight per fruit were significantly highest in cayenne pepper planted at low population density of 18518 plants $\mathrm{ha}^{-1}$. Fruit width and seed production efficiency were not significantly affected by plant population. This is in contrast with the findings of Nerson (2002) who observed that seed yield index varied with plant population densities in muskmelon (Cucumis melo). This result suggests that increased fruit and seed yield on per-hectare basis is attributable to a higher plant population density but results in lower fruit and seed production per plant. The result conforms with the observations of DeViloria et al., (2002) in bell pepper, Decoteau and Hatt Graham (1994) and Amnifard et al., (2010). Yahaya (2008) also observed that the performance of $C$. frutescens was enhanced by wider spacing as the number of fruits per plant and fruit size was reduced at closer spacing.

The result further showed that fruit length was longer although fewer and less robust in cayenne pepper planted at 40000 plants $\mathrm{ha}^{-1}$. This could be due to pronounced competition among the plants. Therefore, plants at higher population are likely to be taller (with less branching) resulting in fewer longer fruits but higher cumulative number of fruits per area resulting in higher seed yield. Sanchez et al., (1993) reported that low plant densities resulted in larger plants that apparently transported photoassimilates from source leaves to sinks at higher rates than smaller plants in bell pepper. Ozer (2003) also observed from his study that summer rapeseed (Brasicca napus) grown at higher plant density produced higher seed yield compared to the lower population density. 
Table 3: Fruit yield $\left(\mathrm{ha}^{-1}\right)$ of 16 cayenne pepper genotypes evaluated under three plant population densities across two cropping years

\begin{tabular}{|c|c|c|c|c|}
\hline \multirow[t]{2}{*}{ Genotype } & \multicolumn{3}{|c|}{ Fruit yield $\left(\mathrm{t} \mathrm{ha}^{-1}\right)$} & \multirow[b]{2}{*}{$\operatorname{LSD}_{(0.05)}$} \\
\hline & 18518 Plants ha ${ }^{-1}$ & 27777 Plants ha ${ }^{-1}$ & 40000 Plants ha ${ }^{-1}$ & \\
\hline Cayenne slim & 3.04 & 6.53 & 6.34 & 1.76 \\
\hline Ata wewe & 3.77 & 7.67 & 7.73 & 3.82 \\
\hline IA $108-3$ & 3.32 & 4.95 & 4.29 & 1.33 \\
\hline Ikire & 5.31 & 10.48 & 11.00 & 2.81 \\
\hline Sakarho & 2.14 & 6.25 & 4.82 & 2.24 \\
\hline Chilli 14 & 6.87 & 13.35 & 14.23 & 2.75 \\
\hline NHV 1B & 6.16 & 13.65 & 11.94 & 4.22 \\
\hline NHV 1A & 5.56 & 10.63 & 11.68 & 1.43 \\
\hline PP9955 - 15 & 9.69 & 17.21 & 22.19 & 4.08 \\
\hline PP0337 - 7562 & 7.85 & 13.92 & 17.52 & 4.14 \\
\hline ICPN $19-07$ & 7.35 & 17.23 & 14.20 & 7.52 \\
\hline PP0437 - 7509 & 8.39 & 15.93 & 16.62 & 7.09 \\
\hline Bird eye 11 & 3.46 & 7.82 & 7.58 & 1.49 \\
\hline PP0438 - 8543 & 5.96 & 12.71 & 12.01 & 3.79 \\
\hline BG 4 & 5.12 & 7.88 & 10.13 & 3.03 \\
\hline BG 3 & 4.28 & 7.58 & 8.93 & 1.64 \\
\hline $\operatorname{LSD}_{(0.05)}$ & 2.71 & 2.72 & 2.70 & \\
\hline
\end{tabular}

Table 4: Seed yield $\left(\mathrm{ha}^{-1}\right)$ of 16 cayenne pepper genotypes evaluated under three plant population densities across two cropping years

\begin{tabular}{|c|c|c|c|c|}
\hline Genotype & & Seed yield per he & & \\
\hline & 18,518 Plants ha ${ }^{-1}$ & 27,777 Plants ha $^{-1}$ & 40,000 Plants ha $^{-1}$ & \\
\hline Cayenne slim & 572.31 & 599.22 & 884.21 & 238.10 \\
\hline Ata wewe & 625.79 & 676.03 & 982.36 & 131.70 \\
\hline IA108-3 & 279.18 & 340.78 & 431.22 & 84.40 \\
\hline Ikire & 310.02 & 334.44 & 501.64 & 98.00 \\
\hline Sakarho & 316.28 & 327.80 & 436.31 & 96.70 \\
\hline Chilli 14 & 630.45 & 809.34 & 1224.10 & 166.20 \\
\hline NHV 1B & 492.60 & 556.74 & 750.00 & 334.00 \\
\hline NHV 1A & 255.18 & 298.74 & 396.72 & 53.50 \\
\hline PP9955 - 15 & 259.51 & 468.80 & 734.77 & 356.20 \\
\hline PP0337 - 7562 & 302.43 & 420.85 & 640.72 & 162.00 \\
\hline ICPN $19-07$ & 622.09 & 675.83 & 830.02 & 298.90 \\
\hline PP0437- 7509 & 459.46 & 585.22 & 855.84 & 159.70 \\
\hline Bird eye 11 & 391.65 & 394.52 & 595.79 & 159.90 \\
\hline PP0438 - 8543 & 338.06 & 426.87 & 569.02 & 179.30 \\
\hline BG 4 & 393.77 & 497.51 & 704.10 & 101.00 \\
\hline BG 3 & 353.07 & 480.91 & 642.70 & 89.30 \\
\hline$L S D(0.05)$ & 96.83 & 152.97 & 167.67 & \\
\hline
\end{tabular}

Table 5: Seed weight of 16 cayenne pepper genotypes evaluated under three plant population densities across two cropping years

\begin{tabular}{lllll}
\hline Genotype & \multicolumn{1}{c}{100 seed weight $(\mathrm{g})$} & \multicolumn{1}{c}{ LSD $(0.05)$} \\
\hline Cayenne slim & 18518 Plants ha $^{-1}$ & 27777 Plants ha $^{-1}$ & 40000 Plants ha $^{-1}$ & 0.015 \\
Ata wewe & 0.412 & 0.392 & 0.403 & 0.002 \\
IA108-3 & 0.324 & 0.320 & 0.318 & 0.008 \\
Ikire & 0.386 & 0.383 & 0.381 & 0.006 \\
Sakarho & 0.408 & 0.405 & 0.404 & 0.010 \\
Chilli 14 & 0.432 & 0.428 & 0.425 & 0.006 \\
NHV 1B & 0.349 & 0.370 & 0.375 & 0.006 \\
NHV 1A & 0.386 & 0.380 & 0.383 & 0.006 \\
PP9955-15 & 0.391 & 0.373 & 0.371 & 0.004 \\
PP0337-7562 & 0.377 & 0.406 & 0.404 & 0.008 \\
ICPN 19-07 & 0.460 & 0.461 & 0.453 & 0.004 \\
PP0437-7509 & 0.447 & 0.432 & 0.433 & 0.008 \\
Bird eye 11 & 0.446 & 0.437 & 0.435 & 0.008 \\
PP0438-8543 & 0.422 & 0.395 & 0.387 & 0.009 \\
BG 4 & 0.444 & 0.429 & 0.420 & 0.004 \\
BG 3 & 0.452 & 0.446 & 0.445 & 0.377 \\
LSD $(0.05)$ & 0.379 & 0.375 & 0.010 & \\
\hline
\end{tabular}


Abdul-Rafiu A.M., Adebisi M.A., Daniel I.O., Bodunde J.G., Ajayi O.O., Muhammad S.M. and Dixon H.G.

Table 6: The Pearson correlation coefficients among fruit and seed yield characters in cayenne pepper genotypes evaluated across three plant population over two years ( $\mathrm{N}$ - 12)

\begin{tabular}{|c|c|c|c|c|c|c|c|c|c|c|c|}
\hline $\begin{array}{l}\text { Fruit and seed } \\
\text { yield character }\end{array}$ & $\begin{array}{l}\text { Single fruit } \\
\text { weight }\end{array}$ & $\begin{array}{l}\text { Fruit weight } \\
\text { Plant }^{-1}\end{array}$ & Fruit length & Fruit width & Fruit yield $\mathrm{ha}^{-1}$ & $\begin{array}{l}\text { No of seeds } \\
\text { fruit }^{-1}\end{array}$ & $\begin{array}{l}100 \text { seed } \\
\text { weight }\end{array}$ & $\begin{array}{l}\text { Seed yield } \\
\text { plt }^{-1}\end{array}$ & $\begin{array}{l}\text { Seed weight } \\
\text { fruit }^{-1}\end{array}$ & SPE & $\begin{array}{l}\text { Seed yield } \\
\mathrm{ha}^{-1}\end{array}$ \\
\hline No of fruit & $-0.449 * *$ & 0.042 & $-0.387^{* *}$ & $-0.275^{* *}$ & 0.037 & $-0.313^{* *}$ & $-0.402^{* *}$ & $0.616^{* *}$ & $-0.380^{* *}$ & $0.546^{* *}$ & $0.454^{* *}$ \\
\hline Single fruit weight & & $0.832^{* *}$ & $0.693^{* *}$ & $0.350^{* *}$ & $0.703^{* *}$ & $0.441^{* *}$ & $0.384^{* *}$ & -0.033 & $0.524^{* *}$ & $-0.756^{* *}$ & -0.105 \\
\hline fruit weight plant & & & $0.590^{* *}$ & $0.275^{* *}$ & $0.850^{* *}$ & $0.440^{* *}$ & $0.365^{* *}$ & $0.422^{* *}$ & $0.527^{* *}$ & $-0.598^{* *}$ & $0.208^{* *}$ \\
\hline Fruit length & & & & $0.279^{* *}$ & $0.580^{* *}$ & $0.326^{* *}$ & $0.452^{* *}$ & -0.015 & $0.453^{* *}$ & $-0.542^{* *}$ & 0.018 \\
\hline Fruit width & & & & & $0.227 * *$ & $0.361^{* *}$ & $0.084^{* *}$ & 0.021 & $0.347^{* *}$ & $-0.277^{* *}$ & 0.078 \\
\hline $\begin{array}{l}\text { Fruit yield } \\
\text { per ha }\end{array}$ & & & & & & $0.365^{* *}$ & $0.313^{* *}$ & $0.357^{* *}$ & $0.440^{* *}$ & $-0.507 * *$ & $0.378^{* *}$ \\
\hline No of seed/fruit & & & & & & & $0.120^{*}$ & $0.446^{* *}$ & $0.939^{* *}$ & $-0.155^{* *}$ & $0.297 * *$ \\
\hline 100 seed weight & & & & & & & & 0.025 & $0.440^{* *}$ & $-0.302 * *$ & -0.010 \\
\hline Seed yield/plt & & & & & & & & & $0.437^{* *}$ & $0.331^{* *}$ & $0.687^{* *}$ \\
\hline Seed weight/fruit & & & & & & & & & & $-0.227 * *$ & $0.290^{* *}$ \\
\hline SPE & & & & & & & & & & & $0.328 * *$ \\
\hline
\end{tabular}

** - Highly significant (1\% level of probability), * - Significant at $5 \%$ level of probability 
The results of this study are similar to those reported for once-over hand-harvested cayenne pepper (Decoteau and Hatt Graham, 1994); multipleharvested bell pepper (Everett and Subramanya, 1983; Stofella and Bryan, 1988); and single machineharvested tabasco pepper (Sundstrom et al., 1984). Adebisi et al., (2005) also corroborated this in sesame with the genotypes performing better in seed yield at medium population density of 166, 667 plants $\mathrm{ha}^{-1}$. The result further demonstrates that fruit and seed yield from 27777 plant population were generally lower compared to 40000 plant population per hectare. Therefore, increasing the plant population to 40000 plants still guarantees significant increase in fruit and seed yield per hectare. These findings are also corroborated by Nerson (2002) in Muskmelon who reported that high plant density produced high seed yield, mainly through the production of relatively numerous small fruits.

Furthermore, it could be observed that the cayenne pepper genotypes also responded differently to plant population environments in terms of number of fruits, single fruit weight, 100 seed weight, seed yield per plant, fruit yield $\left(\mathrm{t} \mathrm{ha}^{-1}\right)$ and seed yield ( $\mathrm{t}$ ha ${ }^{1}$ ). Yaldiz and Ozguven (2011) reported a fruit yield of $9.4-24.4 \mathrm{t} \mathrm{ha}^{-1}$ in their study on yield and yield components of some Capsicum frutescens genotypes. Highest fresh fruit weight per plant (404.3g) in $C$. frutescens and lowest fresh fruit weight per plant of $18.9 \mathrm{~g} \mathrm{ha}^{-1}$ were reported by Yaldiz and Ozguven (2011). A close observation of the seed yield characters among the 16 cayenne pepper genotype under the three plant population environments indicated that Ata wewe had the highest number of fruits which is probably due its small single fruit weight and 100 seed weight under the three plant population environments. The lowest number of fruits per plant recorded in IA108-3 under 40000 plant population probably implies that the genotype is suitable for cultivation under low densities while PP9955-15 responded negatively to low plant population as it recorded lowest number of fruits under 18518 and 27777 plant population density (48.33 and 51.67, respectively). PP9955-15 was the best in terms of single fruit weight which ultimately resulted in highest fruit yield per hectare under the three plant population densities. Although its fruits were not many but its big size could basically be responsible for the higher fruit yield recorded. Also, other top fruit yielding genotypes were PP0337 -7562, ICPN 19-07, PP0437 - 7509 and Chilli 14. Also, 100 seed weight varied among the three plant population utilized in eight genotypes. This implies that variation observed was not due to chance. The best 100 seed weight was exhibited by PP0337-7562 (0.453 - $0.461 \mathrm{~g})$ while Chilli 14 showed the best seed yield per plant (29.14$34.05 \mathrm{~g}$ ) under the three plant population environments. Fruit and seed yield per hectare were also observed to be generally highest under the highest plant population (40000 plants per hectare) followed by 27777 plant population per ha in all the genotypes. Similar findings were reported by Adebisi (2004) in sesame and Nerson (2002) in muskmelon who stated that seed yield was highest in sesame at plant population of 166,667 per ha followed by 133,3333 plants per ha in sesame while in muskmelon highest seed yield was obtained at 12 plants per $\mathrm{m}^{2}$ (from 0.5 to 16 plant per $\mathrm{m}^{2}$ ), although the fruits were relatively small but seed obtained showed best performance in terms of germination, emergence and vigour.

The relationship between the seed yield characters under different plant population densities showed that inverse relationship existed between number of fruits per plant and single fruit weight, fruit length, fruit width, number of seeds per fruit, 100 seed weight, and seed weight per fruit. By implication, the higher the number of fruits the smaller the single fruit weight as the plant cannot go beyond its fruit carrying capacity. The significant negative correlation between the number of seeds per fruit and number of fruits per plant, seed weight per fruit implies that the number of seeds per fruit reduces with increase in number of fruit per plant, 100 seed weight and seed weight per fruit. Nerson (2002) also observed that seed yield in musk melon increased with increase in fruit size due to increase in number of seeds, fruit and mean seed weight. Significant positive correlation was, however, observed between the number of fruit and seed yield per plant and seed production efficiency. The likely implication of this is that increased number of fruits per plant will translate to more seeds which eventually may increase seed weight per plant. Also, as the single fruit weight increases, the fruit weight per plant, fruit length, fruit width, fruit yield $\left(\mathrm{t} \mathrm{ha}^{-1}\right)$, number of seeds per fruit, 100 seed weight and seed weight per fruit are bound to increase. Increasing the single fruit weight consequently reduces seed production efficiency. This shows that more of the weight is concentrated in the fruit flesh rather than seed. It was also observed that the fruit weight per plant is a function of the fruit length, fruit width, 100 seed weight, seed weight per plant and seed weight per fruit. Genotypes and plant population were found to be major determinants of fruit and seed yield characters in cayenne pepper among other factors. Thus, increasing the plant population of cayenne pepper to 40,000 plants $\mathrm{ha}^{-1}$ resulted in highest fruit and seed yield. Quantitatively, fruit yield were increased by 105.1 and $4.24 \%$ over 18518 plants ha ${ }^{-1}$ and 27777 plants ha $^{-1}$, respectively. Similarly, seed yields increased by 68.8 and $40 \%$ over the recommended 18,518 and 27777 plants $\mathrm{ha}^{-1}$, respectively. Genotypes PP9955-15 and Chilli 14 were identified as top yielding genotypes under the three plant population densities for fruit and seed yield respectively. A plant population of 40000 plants per hectare using $50 \mathrm{x} 50 \mathrm{~cm}$ spacing is therefore recommended for cayenne pepper fruit and seed production. Investigation into the seed quality of cayenne pepper under the three plant population may also be necessary and therefore advocated. 


\section{ACKNOWLEDGEMENTS}

The authors appreciate and acknowledge the support of National Horticultural Research Institute (NIHORT), Ibadan and PBST Dept., FUNAAB. The contributions of the academic staff of PBST Dept., and College of Plant Science $\&$ Crop Production, FUNAAB, during the Ph.D. seminars presentation is appreciated and acknowledged.

\section{REFERENCES}

Adebisi M.A. (2004). Variation, Stability and Correlation Studies in Seed Quality and Yield Characters of Sesame. Unpublished Ph.D. Thesis, Department of Plant Breeding \& Seed Technology, Federal University of Agriculture, Abeokuta. p 122

Adebisi M.A., Ajala M.O., Ojo D.K. and Salau A.W. (2005). Influence of plant population density and season on seed yield and its components in sesame genotypes. Journal of Tropical Agriculture (India), 43 (1-2), 13-18

Adetula A.O. and Olakojo S.A. (2006. Genetic characterization and evaluation of some pepper accessions (Capsicum frutescens L.): The Nigerian 'Shombo' Collections. American-Eurasian J. Agric. \& Environ. Sci., 1 (3), 273-281

Ado S.G. and Asiribo O.E. (1989). Influence of chilli pepper weather variables on pepper fruit in Nigerian savanna. Proc. Int. Sym. on Meteo. Hazard and Dev. (ISMH), Lagos Nigeria, October 22-27, 1989, pp: 6, 52-58

Adubasim C.V., Law-Ogbomo K.E. and Obalum S.E. (2017). Sweet potato (Ipomoea batatas) growth and tuber yield as influenced by plant spacing on sandy loam in humid tropical environment. Agro-Science, 16 (3), 46-50

Akintoye H.A., Kintomo A.A. and Adekunle A.A. (2009). Yield and fruit quality of watermelon in response to plant population. Int. J. Vegetable Sci., 15, 369-380

Alam M.S., Saha S.R., Alam M.S. and Alam M.K. (2011). Effect of sowing time and plant spacing on the yield and yield attributes of sweet pepper (Capsicum aпnиит). Bangladesh Journal of Agricultural Resources, 36 (1), 271-278

Aminifard M.H., Aroiee H., Karimpour S. and Nemati H. (2010). Growth and yield characteristics of paprika pepper (Capsicum annum L.) in response to plant density. Asian Journal of Plant Sciences, 9, 276-280

Berke T., Black L.L., Talekar N.S., Wang J.F., Gniffke P., Green S.K., Wang T.C. and Morris R. (2005). Suggested cultural practices for chili pepper. International Co-operators' Guide. Asian Vegetable Research and Development Centre (AVRDC). February 2005, AVRDC Pub \# 05-620. 8 pp.

Decoteau D.R. and Hatt Graham A.H. (1994). Plant spatial arrangement affects growth, yield and pod distribution of cayenne peppers. Hort. Science, 29, 149-151

De-Viloria Z.A., De-Arteaga R. and Torrealba L.T.D. (2002). Growing of pepper (Capsicum annum) in response to different levels of NPK and sowing density. J. Hort. Sci., 72, 1062-1066

Diepenbrock W. (2000). Yield analysis of winter oilseed rape (Brassica napus L.): a review. Field Crops Res., 67, 35-49

Everett P.H. and Subramanya R. (1983). Pepper production as influenced by plant spacing and nitrogen-potassium rates. Proc. Fla. State Hort. Soc., 96, 79-82
FAO (2004). Hot pepper seed and crop production in the Bahamas. Production manual. Prepared by the FAO project in cooperation with the Ministry of Agriculture, Fisheries and Local Government of the Bahamas. 57 pp. Accessed April 20, 2011.

(internet:http://www.fao.org/docrep/007/y5259e/y5259e 0e.htm\#bm14)

George R.A.T. (2009). Vegetable seed production. CABI Publisher. 320 pages.

Grubben G.J.H. and Tahir I.M. (2004). Capsicum species, In: Grubben G. J. H. and Denton O. A. (Editors). Plant Resources of Tropical Africa 2. Vegetables; PROTA Foundation, Wageningen, Netherlands/

Backhugs Publishers, Leiden, Wageningen, Netherland, Pp. 154-163

Herman A., Pathmanathan U., Richard B. and Kadeem M. (2011). Hot Pepper Production Manual for Trinidad and Tobago. CARDI, Trinidad and Tobago. p. 30

Khasmakhi-Sabet A., Sedaghathoor S., Mohammady J. and Olfati A. (2009). Effect of plant density on bell pepper yield and quality. Int. J. Vegetable Sci., 15, 264-271

Nerson H. (2002). Relationship between plant density and fruit and seed production in muskmelon (Cucumis melo). American Journal of Horticultural Science, 127 (5), 855-859

Norman J.C. (1992). Effect of age of transplanting of hot pepper (Capsicum sinensis). Acta Horiticulturae, 53, $42-48$

Obalum S.E., Edeh I.G., Imoh O.N., Njoku O.M., Uzoh I.M., Onyia V.N., Igwe C.A. and Reichert J.M. (2017). Agronomic evaluation of seedbed and mulching alternatives with plant spacing for dry-season fluted pumpkin in coarse-textured tropical soil. Food and Energy Security, 6 (3), 113-122

Ogunbodede B. A. and Ogunremi E.A. (1986). Estimation of sesame (Sesamum indicum L.) yield from yield parameters. Nigerian Journal of Agronomy, 1 (1), 9-13

Ozer H. (2003). The effect of plant population densities on growth, yield and yield components of two spring rapeseed cultivars. Plant Soil Environ., 49 (9), 422426

Sanchez V.M., Sundstrom F.J., McClure G.N. and Lang N.S. (1993). Fruit maturity storage and post-harvest maturatation treatment affects bell pepper (Capsicum annuиm L.) seed quality. Scientia Hort., 54, 191-201

Stoffella P.J. and Bryan H.H. (1988). Plant population influences growth and yields of bell pepper. J. Amer. Soc. Hort. Sci., 113: 835-839

Sundstrom F.J., Thomas C.H., Edward R.L. and Baskin G.R. (1984). Influence of $\mathrm{N}$ and plant spacing on mechanically harvested Tabasco pepper. J. Hort. Sci., 109, 642-645

Yahaya R.A. (2008). Effect of Sheep Manure, Plant Population and Inter-Row Spacing on Growth Yield Components and Yield of Chilli Pepper (Capsicum frutescens L.). Unpublished Ph.D Dissertation. Department of Agronomy, Ahmadu Bello University, Zaria, Nigeria

Yaldiz G. and Ozguven M. (2011). A study of yield and yield components of different ornamental pepper (Capsicum sp) species and lines in Cukurova ecological conditions. Pakistan Journal of Biological Sciences, 14, 273-281 